\title{
The Relationship between the Use of Social Networking Sites and Intellectual Security among Students of Social Work
}

\section{Yahya Abdou Mohamed Gad (Ph.D.)}

Assistant Professor

Ibrahim Sabry. Ahmed (Ph.D.)

Assistant Professor Community Organization Department

Faculty of Social Work - Helwan University, Cairo, Egypt 


\section{The Relationship between the Use of Social Networking Sites and} Intellectual Security among Students of Social Work

\section{Yahya Abdou Mohamed Gad (Ph.D.)}

Assistant Professor

Faculty of Social Work - Helwan University, Cairo, Egypt Ibrahim Sabry. Ahmed (Ph.D.)

Assistant Professor Community Organization Department Faculty of Social Work - Helwan University, Cairo, Egypt

\section{Abstract:}

This study aimed to determine the relationship between the use of social networking sites and intellectual security among students of social work. It also aimed to identify factors to support online intellectual security among social work students. We selected a purposive sample of (145) students (fourth year), the number of males (118), females (27).

The study concluded that there are no statistically significant differences between the mean scores of social work students (males and females) using social networking sites and their impact on the social dimension of intellectual security. However, there were statistically significant differences between the mean scores of social work students (males and females) using social networking sites and their impact on the religious, political and economic dimension of intellectual security. The study also indicated that there are no statistically significant differences between the mean scores of social work students (living in rural and urban areas) using social networking sites on the intellectual security scale.

\section{Keywords:}

Social Networking Sites - Intellectual security - social work students

\section{Introduction:}

Intellectual extremism is a kind of inability to see alternative aspects of an idea. So that the extremist sees his vision as the only consideration (Shabana, 2005, p14).

Intellectual extremism renders the individual imbalanced in thought and behavior, deviant from the moderate path, causing the disintegration of society and fall of states (Shaheen, 2018, p165).

Many studies have proven the effects of intellectual extremism, for example (Azzam \& Abdul Majeed, 2012) indicated that Islam is the religion of moderation and tolerance, and extremism in religion causes damage to society. The study of (Ali \& Ahmed, 2018, 598) 
explains in detail that intellectual extremism results in many behaviours, including: negative thinking, the imposition of ideas on others without accepting dialogue or discussion, adherence to personal opinion and lack of respect for the views of others, support for ideas that destroy values and adherence to abnormal ideas of society and religion.

Youth extremism is one of the topics that is being widely discussed in the scientific and pedagogical community (Davydov, 2015). The analysis of the nature of youth extremism has shown that there is a connection between the extremist tendency, that is an essential property of young people, and extremist manifestations that come about in the community under certain conditions (Zubok \& Chuprov, 2011).

Hence, achieving intellectual security among youth is an important requirement. Intellectual security begins with critical thinking and mind-work and extends to developing opportunities and providing social integration in order to eliminate youth polarization, enhancing the value of work, production and community participation, and maintaining a state of national consensus within societies (Rahman, 2015, p40).

(Mansour, A. S. 2011) confirmed this in his study, where he shows that the trend amongst Saudi university youth is of negativity towards intellectual extremism, as they reject its expressions and practices, especially the religious and social extremism prevalent in Saudi society. The study recommended developing the social and political environment for youth. These results are consistent with the findings of (Al-khataibeh \& Mohammed \& Alaa, 2014) study which indicated that youth in Jordanian universities rejects ideological extremism albeit the presence of some of its indicators.

Furthermore, intellectual security is not only achieved by the rejection of extremism by youth, but requires community effort. A study conducted by (Ghamdi, 2013, p1) stressed the role of the Scout Movement in maintaining intellectual security; cooperating with the police in spreading security culture among youth, and linking scouting approaches to the intellectual problems of young people. Moneim (2014) confirms that community service projects in Egyptian universities are an attempt to integrate groups of students polarized by some extremist groups. In addition, the media plays an important role in promoting intellectual security, it is an effective tool in building the convictions of youth and their beliefs in light of current 
communications and information revolution (Al-Dulaimi, 2015, p325). This leads us to clarify the relationship between information and communication technology (ICT) and youth extremism.

Social networking on the internet has become more popular. It refers to the activity of linking individuals, groups, or machines in a social structure connected by an open or specific focus such as trade, friendship, work, hobbies, ideology, beliefs, prestige, sexuality, profession, preference, or any other specific area of social life (Karatzogianni, 2012, p1574).

Social networking is based on a network structure that allows people to both express their individuality and meet people with similar interests. It can be conducted in person, but is often conducted online. Social networking has revolutionized the way people communicate and share information (Graham, 2013).

There is evidence of a broad range of effects associated with the use of SNS. It includes individual identity and self-expression such as ethnicity or cultural background, cultivating belonging and a sense of collective identity (Hwang, 2013, p420). Therefore, it has an important role in the formation of intellectual security among youth.

In addition, a study by Belasel (2011) indicated that the spread of the phenomenon of media globalization, the internet and social networking sites such as Facebook and Twitter, as well as foreign television channels, has led to work on reforms for Algerian youth to overcome all forms of intellectual deviation, through education and culture. Fawair (2016) showed the broad and active role of social networks as a threat to intellectual security. In addition, he recommended activating legal and social control for those who misuse these networks, using these networks to spread cultural awareness and ethical principles, renewing university policies for the intellectual understanding of students.

UNESCO (2017) released research on youth and violent extremism on social media. A major output of this study is a 16-point recommendation list for member states, the private sector, internet intermediaries, social media, civil society, and internet users. It recommends for instance, that those actors could consider encouraging the participation of youth in decision-making processes, deepen engagement between Member States, civil society organizations and local communities, promote Media and Information Literacy (MIL) strategies, support research on the subject, ensure professional and conflict-sensitive journalistic coverage, manage 
expressions of hate online without compromising rights to freedom of expression, or educate internet users about ethical online behaviour and privacy issues.

The explosion of online hate is a matter of growing alarm as the detrimental effects of exposure to it are well documented, and youth and young adults may be especially at risk. For many youths, the internet is the port of entry for information on topics with which they are unfamiliar, and hate mongers, keenly aware of this, use the internet to target and recruit youth. It is incumbent upon adults to recognize the risk factors associated with exposure to online hate. Understanding where young people see hate online is a first step in helping youth appreciate the risks that online hate poses. In doing so, we hope young people will be better prepared to process and contextualize the hateful information they encounter (Costello \& others, 2018, p 14).

Social work has only recently examined the use of social media and other online technologies in social work practice. These have crept into practice and revolutionised communication between practitioners and service users (Mishna \& Others, 2012). Professional associations of social work have prepared online ethical guidelines for social media use. For example, the Australian Association of Social Workers (AASW) 2016 released guidelines for social media. These include rules and guidelines for authorised use of social media on behalf of AASW and personal forms of social media. In the United States, NASW, ASWB, CSWE, \& CSWA (2017) released standards for technology in social work practice. These centred on 'Provision of Information to the Public', 'Designing and Delivering Services', 'Gathering, Managing, and Storing Information', and 'Social Work Education and Supervision'.

Social work literature has called for graduate competence in using social media (Robbins \& Singer, 2014), with an increasing number of educators using social media in teaching (Kilpeläinen \& Others, 2011). This is due to the dangers facing students and graduates of social work because they are unaware of the ethical issues and the importance of maintaining professional behaviour and boundaries in online spaces (Mukherjee \& Clark, 2012).

This study aims to determine the relationship between the use of social networking sites and intellectual security among social work students. 


\section{Study Objectives:}

1. Determine the relationship between the use of social networking sites and intellectual security among the students of social work who use these sites.

2. Identify indicators to support online intellectual security among social work students.

\section{Study hypotheses:}

1. First Hypothesis: There are statistically significant differences between the mean scores of social work students (males and females) who use social networking sites on the intellectual security scale.

2. Second Hypothesis: There are statistically significant differences between the mean scores of social work students (living in rural and urban areas) who use social networking sites on the intellectual security scale.

\section{Study concepts:}

\section{Intellectual security:}

Intellectual security is defined as a sense of spiritual, psychological, physical, mental and physical security that does not conflict with the religion, principles or ethics of the individual or society, and does not affect the thoughts and lives of others (Said, 2011, p19).

Intellectual security is described as one of the most important components of national security for all communities, alongside agricultural, environmental, health and food security (Hallil, 2016, p64). It seeks to fully protect human thought from deviation by strengthening the cultural, moral and security system to be able to confront any extremist or deviant thought or behavior (Mohsen, 2017, p254)

It is also defined as the intellectual reference of a society that is compatible with its economic, social, political and cultural conditions that vary with other societies (Ahmed, 2015, p495).

\section{The operational definition of intellectual security:}

Intellectual security: the intellectual reference that achieves social, religious, political and economic security for social work students which does not conflict with their religious or moral values and makes them pioneers of social peace. 


\section{Theoretical Guidelines of the Research:}

\section{1- Social Networking Theory:}

Social networking theory examines the patterns and characteristics of social connections and their relationship to the lives of individuals and their social organization. This theory uses a framework to study how people are connected to each other through computer networks. These include network structure, network size, network range, and communication frequency between people, density of interpersonal links, member characteristics, network history, and available network resource (Rahooma, 2002, p65).

Network theory is based on a set of basic assumptions, most importantly these include:

1. Network construction which focuses on two areas. The first is global networking: a global interactive structure that includes topics of a global scope that do not belong to a particular ethnic group or minority, but all minorities and cultural disparities are embedded within the global network's interconnectedness. The second is local social networks, showing the role of local groups that have created units within global interactions with a focus on local issues and policies (Robins \& Kashima, 2008, p5).

2. Information exchange which allows people to update their beliefs about the costs and benefits inherent in participation, and so change their decisions. Networks can also coordinate and transfer resources, which have an independent effect on one's willingness to participate (Sidney\& Others, 1995).

\section{2- Online activism model:}

Vegh's (2003) classification of online activism includes: (a) awareness/advocacy, and (b) organization/mobilization. First, when it comes to awareness and advocacy, the worldwide web enables the bypassing of traditional media gatekeepers. Second, the internet facilitates organization and mobilization by three means: a) calling for offline action via email or a website; b) calling for online action for something typically done offline, such as sending emails to Congress members instead of letters; and c) calling for online action that is possible only via the internet.

\section{Methodology:}

The present study is a descriptive study aimed at determining the relationship between the use of social networking sites and intellectual security for social work students. The study, based on a sample social survey methodology of social work students (Fourth Year) in the social work faculty at Helwan University in Cairo, Egypt. The study was implemented during the period from 3/3/2017 to $30 / 4 / 2017$. 


\section{Population:}

The sample frame includes social work students (fourth year), their numbers were (1950) students, then a purposive sample of (145) students was selected according to the following conditions:

1. Regular students who attend faculty curriculum.

2. Students who have pages on social networking sites (Facebook or Twitter or Instagram).

3. Students with high e-participation on social networking. Tool:

The current study used an intellectual security scale developed by researchers to determine the relationship between the use of social networking sites and intellectual security for social work students.

The Design of the tool: The intellectual security scale was designed according to the following steps: Researchers benefit from previous studies on intellectual security and ICT. These studies included Belasel, M. Study (2011), UNESCO (2017) study and Matthew Costello \& others study (2018). This scale consists of (4) dimensions that include (47) items distributed between them as shown in table (1). The answer on the scale items are determined as follows: Agree $=3$ degrees, Partially Agree $=2$ degrees, Do not agree $=1$ degree. To calculate the levels of intellectual security of social work students as a result of the use of social networking sites, we used the arithmetic mean as shown in Table (2).

Table (1) - the dimensions of the tool and the number of items

\begin{tabular}{||c||c||c||}
\hline \hline S & \multicolumn{1}{|c||}{ Dimensions } & $\begin{array}{c}\text { Number } \\
\text { of items }\end{array}$ \\
\hline \hline 1 & $\begin{array}{l}\text { Use of social networking sites and the social } \\
\text { dimension of intellectual security }\end{array}$ & 12 \\
\hline \hline 2 & $\begin{array}{l}\text { Use of social networking sites and the religious } \\
\text { dimension of intellectual security }\end{array}$ & 12 \\
\hline \hline 3 & $\begin{array}{l}\text { Use of social networking sites and the political } \\
\text { dimension of intellectual security }\end{array}$ & 8 \\
\hline \hline 4 & $\begin{array}{l}\text { Use of social networking sites and the economic } \\
\text { dimension of intellectual security }\end{array}$ & 47 \\
\hline \hline \multicolumn{2}{|c|}{ Total dimensions } \\
\hline
\end{tabular}




\begin{tabular}{||lcc|}
\hline \multicolumn{2}{|l|}{ Egyptian Journal of Social Work (EJSW) } & \multicolumn{1}{c|}{ http://ejsw.journals.ekb.eg } \\
Print ISSN: $2356-9204$ & Online ISSN: 2356-9212 & Vol 8, Issue 1, June 2019 \\
\hline
\end{tabular}

Table (2) - The arithmetic mean levels of items and dimensions of scale

Equal to mean value of item or dimension ranged between 1 and 1.66

Low levels

Equal to mean value of item or dimension ranged between 1.67 and 2.33

Equal to mean value of item or dimension ranged

between 2.34 and 3

Medium level

Validity and Reliability of the Study Tool:

- Face validity: The scale was judged by (7) members of the community organization department in the faculty of social work at Helwan University. The members' agreement rate of more than $80 \%$ approved the scale.

- Validity of internal consistency: The researchers use internal consistency by applying the scale to a sample of (10) social work students (males and females). The tables below presents results of internal consistency.

Table (3) - The correlation coefficients between every item and the dimension to which it belongs

\begin{tabular}{|c|c|c|c|c|c|c|c|}
\hline \multicolumn{2}{|c|}{$\begin{array}{c}\text { Social dimension } \\
\text { of intellectual } \\
\text { security } \\
\end{array}$} & \multicolumn{2}{|c|}{$\begin{array}{c}\text { Religious } \\
\text { dimension of } \\
\text { intellectual security } \\
\end{array}$} & \multicolumn{2}{|c|}{$\begin{array}{c}\text { Political dimension } \\
\text { of intellectual } \\
\text { security } \\
\end{array}$} & \multicolumn{2}{|c|}{$\begin{array}{c}\text { Economic } \\
\text { dimension of } \\
\text { intellectual security }\end{array}$} \\
\hline $\begin{array}{c}\text { No. } \\
\text { of } \\
\text { item }\end{array}$ & $\begin{array}{l}\text { correlation } \\
\text { coefficient }\end{array}$ & $\begin{array}{c}\text { No. } \\
\text { of } \\
\text { item }\end{array}$ & $\begin{array}{l}\text { correlation } \\
\text { coefficient }\end{array}$ & $\begin{array}{c}\text { No. } \\
\text { of } \\
\text { item }\end{array}$ & $\begin{array}{c}\text { correlation } \\
\text { coefficient }\end{array}$ & $\begin{array}{c}\text { No. } \\
\text { of } \\
\text { item }\end{array}$ & $\begin{array}{l}\text { correlation } \\
\text { coefficient }\end{array}$ \\
\hline 1 & $0.62 * *$ & 1 & $0.56 * *$ & 1 & $0.72 * *$ & 1 & $0.51 * *$ \\
\hline 2 & $0.74 * *$ & 2 & $0.66 * *$ & 2 & $0.59 * *$ & 2 & $0.66 * *$ \\
\hline 3 & $0.66 * *$ & 3 & $0.75 * *$ & 3 & $0.73 * *$ & 3 & $0.75 * *$ \\
\hline 4 & $0.55 * *$ & 4 & $0.69 * *$ & 4 & $0.68 * *$ & 4 & $0.80 * *$ \\
\hline 5 & $0.75 * *$ & 5 & $0.75 * *$ & 5 & $0.71 * *$ & 5 & $0.74 * *$ \\
\hline 6 & $0.72 * *$ & 6 & $0.69 * *$ & 6 & $0.74 * *$ & 6 & $0.61 * *$ \\
\hline 7 & $0.63 * *$ & 7 & $0.63 * *$ & 7 & $0.66 * *$ & 7 & $0.75 * *$ \\
\hline 8 & $0.60 * *$ & 8 & $0.69 * *$ & 8 & $0.66 * *$ & 8 & $0.67 * *$ \\
\hline 9 & $0.66^{* *}$ & 9 & $0.66^{* *}$ & 9 & $0.69 * *$ & --- & ---- \\
\hline 10 & $0.67 * *$ & 10 & $0.69 * *$ & 10 & $0.68 * *$ & --- & ---- \\
\hline 11 & $0.68 * *$ & 11 & $0.70 * *$ & 11 & $0.72 * *$ & --- & ---- \\
\hline 12 & $0.66 * *$ & 12 & $0.63 * *$ & 12 & $0.72 * *$ & --- & ---- \\
\hline--- & --- & ---- & --- & 13 & $0.71 * *$ & --- & ---- \\
\hline --- & --- & ---- & --- & 14 & $0.74 * *$ & --- & $\begin{array}{l}--- \\
\end{array}$ \\
\hline --- & --- & ---- & --- & 15 & $0.75 * *$ & --- & ---- \\
\hline
\end{tabular}




\begin{tabular}{||lcc||}
\hline \multicolumn{2}{|l|}{ Egyptian Journal of Social Work (EJSW) } & http://ejsw.journals.ekb.eg \\
Print ISSN: 2356-9204 & Online ISSN: 2356-9212 & Vol 8, Issue 1, June 2019 \\
\hline \hline
\end{tabular}

Table (3) shows that all dimensions relate to each other and with the whole degree of the scale, with a statistically significant correlation at a significant level (0.01). This confirms certainty for the construct validity.

Table (4) - The correlation coefficients between the score of each

dimension included in the scale and the total score of the scale

\begin{tabular}{||c||c||c||}
\hline S & Dimensions & $\begin{array}{c}\text { Value of Pearson } \\
\text { coefficient }\end{array}$ \\
\hline \hline 1 & Social dimension of intellectual security & $0.88^{* *}$ \\
\hline \hline 2 & Religious dimension of intellectual security & $0.92^{* *}$ \\
\hline \hline 3 & Political dimension of intellectual security & $0.94^{* *}$ \\
\hline \hline 4 & Economic dimension of intellectual security & $0.86^{* *}$ \\
\hline \hline
\end{tabular}

** Significance at (0.01)

* Significance at $(0.05)$

Table (4) shows that all correlation coefficients are statistically significant at level (0.01). This confirms certainty for the construct validity.

\section{Measurement of scale reliability:}

Table (5) - Results of the Reliability of intellectual security scale using the Alpha Cronbach Coefficient

\begin{tabular}{|c|c|c|c|}
\hline $\mathbf{S}$ & Dimensions & $\begin{array}{l}\text { N. of } \\
\text { items }\end{array}$ & $\begin{array}{l}\text { Alpha } \\
\text { Cronbach } \\
\text { Coefficient }\end{array}$ \\
\hline 1 & $\begin{array}{l}\text { Use of social networking sites and the } \\
\text { social dimension of intellectual security }\end{array}$ & 12 & 0.91 \\
\hline 2 & $\begin{array}{l}\text { Use of social networking sites and the } \\
\text { religious dimension of intellectual } \\
\text { security }\end{array}$ & 12 & 0.88 \\
\hline 3 & $\begin{array}{l}\text { Use of social networking sites and the } \\
\text { political dimension of intellectual } \\
\text { security }\end{array}$ & 15 & 0.87 \\
\hline 4 & $\begin{array}{l}\text { Use of social networking sites and the } \\
\text { economic dimension of intellectual } \\
\text { security }\end{array}$ & 8 & 0.92 \\
\hline & Total dimensions & 47 & 0.92 \\
\hline
\end{tabular}

The table above shows that most coefficients of the variables have a high degree of reliability, thus their results are reliable. 


\section{Study results:}

Table (6) - Characteristics of the study sample $(\mathrm{N}=145)$

\begin{tabular}{|c||c||c||c||}
\hline $\mathbf{S}$ & gender & $\mathbf{N}$ & $\mathbf{\%}$ \\
\hline \hline 1 & Male & 118 & 81.4 \\
\hline \hline 2 & female & 27 & 18.6 \\
\hline \hline $\mathbf{S}$ & Social status & $\mathbf{N}$ & $\mathbf{\%}$ \\
\hline \hline 1 & Single & 114 & 78.6 \\
\hline \hline 2 & Married & 29 & 20 \\
\hline \hline 3 & Divorced & 2 & 1.4 \\
\hline \hline $\mathbf{S}$ & Economic status & $\mathbf{N}$ & $\mathbf{\%}$ \\
\hline \hline 1 & Low & 16 & 11 \\
\hline \hline 2 & Medium & 123 & 84.8 \\
\hline \hline 3 & High & 6 & 4.1 \\
\hline \hline $\mathbf{S}$ & Location & $\mathbf{N}$ & $\mathbf{\%}$ \\
\hline \hline 1 & Rural area & 55 & 37.9 \\
\hline \hline 2 & Urban area & 90 & 62.1 \\
\hline \hline & Total & 145 & $100 \%$ \\
\hline
\end{tabular}

The table above shows that:

- The highest percentage of social work students were male $(81.7 \%)$, while females were $(18.6 \%)$.

- The highest percentage of social work students were single (78.6\%), while the percentage married was (20\%), divorcees represented the lowest percentage $(1.4 \%)$.

- The highest percentage for economic status of social work students was Medium (84.8\%), while (11\%) of students' economic status was low, while the percentage of students with high economic status was $(4.1 \%)$.

- A high percentage of social work students live in urban areas $(62.1 \%)$, while the percentage of students in rural areas is $(37.9 \%)$. 
Table (7) - Use of social networking sites and the level of intellectual security for students of social work

\begin{tabular}{||c||c||c||c||c||}
\hline \hline$S$ & Dimensions & Mean & S.D & Level \\
\hline \hline 1 & $\begin{array}{c}\text { Use of social networking sites and the social } \\
\text { dimension of intellectual security }\end{array}$ & 2.33 & 0.51 & medium \\
\hline \hline 2 & $\begin{array}{c}\text { Use of social networking sites and the } \\
\text { religious dimension of intellectual security }\end{array}$ & 2.22 & 0.53 & medium \\
\hline \hline 3 & $\begin{array}{c}\text { Use of social networking sites and the political } \\
\text { dimension of intellectual security }\end{array}$ & 2.21 & 0.55 & medium \\
\hline \hline 4 & $\begin{array}{c}\text { Use of social networking sites and the } \\
\text { economic dimension of intellectual security }\end{array}$ & 2.30 & 0.55 & medium \\
\hline \hline \multicolumn{2}{|c|}{ Total } & 2.26 & 0.48 & medium \\
\hline
\end{tabular}

The table above shows that the levels of intellectual security dimensions for social work students who use social networking sites. It is clear that all dimensions have reached a medium level. In addition, it is clear that the level of intellectual security for students of social work is medium ( mean $=2.26, \mathrm{SD}=0.48)$.

Table (8) -Significant Differences between the Mean Scores of social work students (males and females) who use social networking sites on the intellectual security scale using T-Test $(\mathrm{N}=145)$

\begin{tabular}{|c|c|c|c|c|c|c|c|c|}
\hline $\mathbf{S}$ & Dimensions & \multicolumn{2}{|c|}{ gender } & Mean & (SD) & $\begin{array}{c}\text { T } \\
\text { value }\end{array}$ & DF & Sig \\
\hline \multirow{2}{*}{1} & \multirow{2}{*}{$\begin{array}{l}\text { The social dimension } \\
\text { of intellectual security }\end{array}$} & $\mathrm{M}$ & 118 & 2.36 & 0.47 & \multirow{2}{*}{1.680} & \multirow{2}{*}{143} & \multirow{2}{*}{$\begin{array}{c}\text { Non- } \\
\text { Significant }\end{array}$} \\
\hline & & $\mathrm{F}$ & 27 & 2.18 & 0.63 & & & \\
\hline \multirow[b]{2}{*}{2} & \multirow{2}{*}{$\begin{array}{c}\text { The religious } \\
\text { dimension of } \\
\text { intellectual security }\end{array}$} & M & 118 & 2.26 & 0.50 & \multirow[b]{2}{*}{2.066} & \multirow[b]{2}{*}{143} & \multirow[b]{2}{*}{ * } \\
\hline & & $\mathrm{F}$ & 27 & 2.03 & 0.64 & & & \\
\hline \multirow[b]{2}{*}{3} & \multirow{2}{*}{$\begin{array}{l}\text { The political } \\
\text { dimension of } \\
\text { intellectual security }\end{array}$} & $\mathrm{M}$ & 118 & 2.26 & 0.53 & \multirow[b]{2}{*}{2.225} & \multirow[b]{2}{*}{143} & \multirow[b]{2}{*}{$*$} \\
\hline & & $\mathrm{F}$ & 27 & 2.00 & 0,61 & & & \\
\hline \multirow[b]{2}{*}{4} & \multirow{2}{*}{$\begin{array}{c}\text { The economic } \\
\text { dimension of } \\
\text { intellectual security }\end{array}$} & $\mathrm{M}$ & 118 & 2.35 & 0.53 & \multirow[b]{2}{*}{2.458} & \multirow[b]{2}{*}{143} & \multirow[b]{2}{*}{$*$} \\
\hline & & $\mathrm{F}$ & 27 & 2.06 & 0.60 & & & \\
\hline \multicolumn{5}{|c|}{$* *$ Significance at $(0.01)$} & \multirow{2}{*}{\multicolumn{4}{|c|}{ * Significance at (0.05) }} \\
\hline & $\mathbf{M}=$ males & & $\mathbf{F}=$ & ma & & & & \\
\hline
\end{tabular}




\section{The table above shows that:}

- There are no statistically significant differences between the mean scores of social work students (males and females) who use social networking sites and their impact on the social dimension of intellectual security.

- There were statistically significant differences (0.05) between mean scores of social work students (males and females) who use social networking sites and their impact on the religious dimension of intellectual security. The significance is for male.

- There were statistically significant differences (0.05) between mean scores of social work students (males and females) who use social networking sites and their impact on the political dimension of intellectual security. The significance is for male.

- There were statistically significant differences (0.05) between mean scores of social work students (males and females) who use social networking sites and their impact on the economic dimension of intellectual security. The significance is for male.

Thus, we partially accept the first hypothesis of the study "There are statistically significant differences between the mean scores of social work students (males and females) who use social networking sites on the intellectual security scale".

Table (9) -Significant Differences between the Mean Scores of social work students (living in rural and urban areas) using social networking sites on the intellectual security scale using T-Test $(\mathrm{N}=145)$

\begin{tabular}{|c|c|c|c|c|c|c|c|c|}
\hline $\mathbf{S}$ & Dimensions & \multicolumn{2}{|c|}{ Location } & Mean & (SD) & $\begin{array}{c}\mathrm{T} \\
\text { value }\end{array}$ & DF & Sig \\
\hline \multirow[b]{2}{*}{1} & \multirow{2}{*}{$\begin{array}{l}\text { The social dimension of } \\
\text { intellectual security }\end{array}$} & $\mathrm{R}$ & 55 & 2.31 & 0.45 & \multirow{2}{*}{0.345} & \multirow{2}{*}{143} & \multirow[b]{2}{*}{$\begin{array}{c}\text { Non- } \\
\text { Significant }\end{array}$} \\
\hline & & $\mathrm{U}$ & 90 & 2.34 & 0.54 & & & \\
\hline \multirow{2}{*}{2} & \multirow{2}{*}{$\begin{array}{c}\text { The religious dimension of } \\
\text { intellectual security }\end{array}$} & "R & 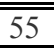 & 2.27 & 0.52 & \multirow{2}{*}{0.906} & \multirow{2}{*}{143} & \multirow{2}{*}{$\begin{array}{c}\text { Non- } \\
\text { Significant }\end{array}$} \\
\hline & & $\overline{\mathrm{UU}}$ & 90 & 2.19 & 0.54 & & & \\
\hline \multirow{2}{*}{3} & \multirow{2}{*}{$\begin{array}{c}\text { The political dimension of } \\
\text { intellectual security }\end{array}$} & "R & 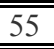 & 2.26 & $\begin{array}{l}0.50 \\
\end{array}$ & \multirow{2}{*}{0.919} & \multirow{2}{*}{143} & \multirow{2}{*}{$\begin{array}{c}\text { Non- } \\
\text { Significant }\end{array}$} \\
\hline & & $\overline{\mathrm{U}}$ & 90 & 2.18 & 0.58 & & & \\
\hline \multirow{2}{*}{4} & \multirow{2}{*}{$\begin{array}{l}\text { The economic dimension } \\
\text { of intellectual security }\end{array}$} & $\begin{array}{l}\mathrm{R} \\
\end{array}$ & 55 & 2.33 & 0.49 & \multirow{2}{*}{0.576} & \multirow{2}{*}{143} & \multirow{2}{*}{$\begin{array}{c}\text { Non- } \\
\text { Significant }\end{array}$} \\
\hline & & 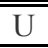 & 90 & 2.28 & 0.59 & & & \\
\hline
\end{tabular}

** Significance at (0.01)

$\mathbf{R}=$ rural areas

$\mathrm{U}=$ urban areas

* Significance at (0.05) 
The table above shows that there are no statistically significant differences between the mean scores of social work students (living in rural and urban areas) who use social networking sites on the intellectual security scale.

Thus, we reject the second hypothesis of the study "There are statistically significant differences between the mean scores of social work students (living in rural and urban areas) who use social networking sites on the intellectual security scale".

\section{Discussion:}

Understanding the relationship between the use of social networking sites and intellectual security has never been timelier.

The current study contributes in general to filling the gap in the field of social work and ICT, especially in the social media field, where (Mishna \& Others, 2012) explained that social work has only recently examined the use of social media and other online technologies in social work practice.

In addition, Arab communities in general, and the Egyptian community in particular, need to fill the gap in the literature that links social work with social media. As noted, previous studies focused on examining the effects of social media without mentioning the role of the social work profession.

Therefore, the current study can help to fill this gap by focusing on the issue of online intellectual security between social work students, especially due to the spread of extremism and terrorism which has moved into cyberspace.

Results from the t-test highlight that gender related to intellectual security on social networking sites. There were statistically significant differences between mean scores of social work students (males and females) who use social networking sites and their relationship to the religious, political and economic dimensions of intellectual security. The significance is for males. This may be due to male dissatisfaction with the political, religious and economic life of Egyptian society, which makes them vulnerable to individuals and groups that respond to their political, economic and religious struggles and attract them to extremist thought. Therefore, attention must be paid to (Costello \& others, 2018) study, which indicated that the explosion of online hate is a matter of growing alarm as the damaging effects of exposure to it are well documented, and youth and young adults may be especially at risk. 
Thus, male social work students are considered vulnerable to the dangers of intellectual security on social networking sites and must improve their efficiency in the use of social media. As (Robbins \& Others, 2014) indicated, social work literature has called for graduate competency in using social media.

This may also mean that female social work students in Egyptian society do not participate significantly in addressing political, economic and religious issues on social networking sites due to their interest in supporting social issues. This is evident in the absence of any difference between the mean scores of social work students (males and females) who use social networking sites and their impact on the social dimension of intellectual security.

The current study substantiated the standards of the National Association of Social Workers (2017) associated with the use of technology in social work practice that include: a) Training social workers in the use of technology in practice, b) social work educators shall provide students with social media policies to give them guidance for ethical considerations.

The study also proved that there are no statistically significant differences between the mean scores of social work students (living in rural and urban areas) who use social networking sites on the intellectual security scale. Therefore, attention should be paid to involving rural and urban social work students in the formulation and renewing of intellectual security policies at the university level. These results are consistent with Fawair (2016) study that recommended renewed university policies for the intellectual understanding of students.

In addition, the results of the current study showed that the level of intellectual security dimensions of social work students who use social networking sites has reached medium. This may be because of several reasons, for example:

a. The interest of faculty members in using social networking sites to strengthen their interaction with social work students and to prevent any ideas or rumors that might lead them to adopt an extremist ideology.

b. The students' ignorance of how to practice social work online.

c. Social networking sites are not continuously monitored by students because they are busy looking for job opportunities.

d. Students of social work adhere to religious and moral values that make them think positively about the uses of social media. 
The previous findings support the theory of social networks and their assumption that network construction focuses on a global interactive structure that includes topics of a global scope that do not belong to a particular ethnic group or minority, but all minorities and cultural disparities are embedded within the global network's interconnectedness. Hence, intellectual extremism occurs because of the lack of good leadership that mobilizes cultural and ethnic diversity for the common good. Vegh's model (2003) shows how to mobilize people through the internet, but does not explain who will lead people online.

This leads us to a conclusion that "online leadership" is one of the topics that needs to be addressed when examining intellectual security issues through social networking sites, and which should be the focus of future studies in social work education and practice.

The results lead to a set of indicators to support online intellectual security among social work students:

1. The attention of the youth welfare department in awareness raising activities about extremist ideology among the students of social work.

2. Involving rural and urban social work students in the formulation and renewing of intellectual security policies at the university level.

3. Attention to the activities of the Ministry of Youth to spreading the idea of social and cultural peace among students of social work.

4. Establishing intellectual security departments in Egyptian universities.

\section{Recommendations:}

The current study recommends:

1. Integration of ICT in social work education through the preparation of a new curriculum entitled "online social work" to develop students' knowledge for dealing with the issues and challenges of online professional practice.

2. Include the subject of electronic terrorism within social work courses.

3. Pay attention to teaching positive and critical thinking among social work students and how to practice it on social networking sites.

4. Incorporate online leadership into the research policies of social work faculties.

5. Preparation of Egyptian professional standards for the use of social networking sites in the practice of social work. 


\section{References:}

AASW. (2016). AASW Social Media Guidelines. North Melbourne, Australia: Australian Association of Social Workers .

Ahmed, S. H. (2015). The role of intellectual security in achieving social peace. Journal of the Faculty of Law for Legal and Political Sciences, Volume 4, Number 12, 495.

Al-Dulaimi, H. A. (2015). The role of media in promoting intellectual security among youth. Journal of Anbar University of Islamic Sciences, Volume 6, No.23, 325.

Belasel, M. (2011). The phenomenon of using the revolution of modern communication technology for intellectual security in Algeria. Journal of Law and Humanities, No. 9, 104.

Davydov, D. (2015). The Causes of Youth Extremism and Ways to Prevent It in the Educational Environment. Russian Social Science Review, Vol.56, $\mathrm{N}$ 5,51 .

Erba, Sidney, Kay L. Schlozman, and Henry E. Brady. (1995). Voice and Equality: Civic Voluntarism in American Politics. Cambridge, MA: Harvard University Press.

Fawair, H. Y. (2016). The impact of social networks on the intellectual security of university youth in Jordan: The views of the students of Irbid University College - Balqa University. Journal of Education, Faculty of Education, Al-Azhar University, No.169, No.2, 529.

Garry Robins, Yoshi Kashima. (2008). Social psychology and social networks: Individuals andsocial systems. Asian Journal of Social Psychology, Vol.11, 1-12.

Ghamdi, A. b. (2013). The Role of Scout Leaders in Enhancing Intellectual Security among Youth in Riyadh. Master Thesis, Faculty of Graduate Studies, Naif Arab University for Security Sciences, 1.

Graham, M. W. (2013). Social networking. In R. L. Heath (Ed.), Encyclopedia of public relations (Vol.1, pp.851-851). Thousand Oaks, CA: SAGE Publications, Inc.

Hallil, A. A. (2016). Intellectual security as a concept. Journal of Security and Life, Volume 35, Issue 407, 64.

Haward, R. (1993). Virtual Community. Retrieved from http//:www.com .user/h(R)Vcboal.

Hwang, H. J. (2013). Benefits and Challenges of Social Networks in Kazakhstan. International Journal of Software Engineering and Its Applications, Vol.7, No.4, 420.

Karatzogianni, A. (2012). Social networking. In H. K. Anheier \& M. Juergensmeyer (Eds.), Encyclopedia of global studies (Vol.1, pp.1574-1576). Thousand Oaks, CA: SAGE Publications, Inc.

Kilpeläinen, A., Päykkönen, K. \& Sankala, J. (2011). The use of social media to improve social work education in remote areas. Journal of Technology in Human Services, Vol.29, N 1, 1-12. 
Maha Azzam Hamad, Aqeel Abdul Majeed. (2012). Extremism and its impact on society. Master Thesis, Faculty of Education, University of Tikrit, Iraq.

Mansour, A. S. (2011). Saudi Youth Attitudes Towards the Phenomenon of Intellectual Extremism: A Social Study on a Sample of Qaseem University Students. Master Thesis, College of Graduate Studies, University of Jordan, 1.

Matthew Costello, Rebecca Barrett-Fox, Colin Bernatzky, James Hawdon, Kelly Mendes. (2018). Predictors of Viewing Online Extremism Among America's Youth. Youth \& Society, Vol.00, N 0, 14.

Mishna, F., Bogo, M., Root, J., Sawyer, J.-L., \& Khoury-Kassabri, M. (2012). "It just crept in": The digital age and implications for social work practice. Clinical Social Work Journal, Vol.40, 277.

Mohamed Ali Mohamed Kassem, Khaled Ahmed Abdel Aal. (2018). The impact of intellectual extremism on the safety of society from the perspective of teachers. Journal of Faculty of Education, Assiut University, Volume 34, Issue 1, 598.

Mohsen, M. K. (2017). Islamic perception of intellectual security. Journal of the Nile Basin Studies, Volume 10, Number 20, 254.

Moneim, M. A. (2014). Intellectual Security and Community Service Projects: An Approach to Address Violence among University Youth. Journal of educational and psychological studies, No.83, 23.

Mukherjee, D., \& Clark, J. (2012). Students' participation in social networking sites: Implications for social work education. Journal of Teaching in Social Work, Vol.32, 161-173.

NASW. (2017). standards for technology in social work. Washington, DC: National Association of Social Workers.

Omori, K. (2017). Social networks, online. In M. Allen (Ed.), The sage encyclopedia of communication research methods (pp. 1641-1643). Thousand Oaks, CA: SAGE Publications.

Rahman, A. R. (2015). Intellectual Security: Levels of Thinking and Application Trends. Obeikan Center for Research and Publishing, Issue 11, 40.

Rahooma, A. M. (2002). Cybernetics Sociology. Kuwait: National Council for Culture, Arts.

Robbins, S. P. \& Singer, J. B. (2014). From the editor-The medium is the message: Integrating social media and social work education. Journal of Social Work Education, Vol.50, $N$ 3, 387-390.

S, V. (2003). Classifying forms of online activism: The case of cyberprotests against the World Bank. In McCaughey $M$ and Ayers MD (eds) Cyberactivism: Online Activism in Theory and. New York: Routledge.

Said, A. A. (2011). Intellectual Security Establishment: the International Institute of Islamic Thought Model . Journal of Law and Humanities, Issue 9, 19. 


\begin{tabular}{|llc||}
\hline \multicolumn{2}{|l|}{ Egyptian Journal of Social Work (EJSW) } & http://ejsw.journals.ekb.eg \\
Print ISSN: 2356-9204 & Online ISSN: 2356-9212 & Vol 8, Issue 1, June 2019 \\
\hline \hline
\end{tabular}

Shabana, M. K. (2005). Intellectual extremism in our lives: its motives and treatment. Islamic awareness journal, Vol.472, N 41, 14.

Shaheen, I. M. (2018). The effects of intellectual extremism on the safety of the individual and society. Arabic and Islamic studies journal, Vol.71, 165172.

UNESCO. (2017). YOUTH AND VIOLENT EXTREMISM ON SOCIAL MEDIA:MAPPING THE RESEARCH. France: United Nations Educational, Scientific and Cultural Organization.

Williams, J. (2010). Social Networking Applications in Health Care: Threats to the Privacy and Security of Health Information. Proceedings of the 2010. ICSE Workshop on Software Engineering in Health Care (pp.3949). Cape Town, South Africa: ACM.

Yousef Al-Khatayba, M. T. (2014). Factors and manifestations of ideological extremism as perceived by Jordanian university youth: A sociological and empirical study. Journal of Social Sciences, Volume 42, Issue 3, 9.

Zubok, I. A., \& Chuprov, V. I. (2011). Self-Organization in the Manifestations of Youth Extremism. Russian Education \& Society, Vol.53, N 2,26 . 